\title{
Ridleyandra iminii (Gesneriaceae), a new species from Peninsular Malaysia
}

\author{
Mat Yunoh Siti-Munirah' \\ I Forest Research Institute Malaysia, 52109 Kepong, Selangor, Malaysia \\ Corresponding author: Mat Yunoh Siti-Munirah (sitimunirah@frim.gov.my)
}

Academic editor:Alan Paton | Received 28 September 2012 | Accepted 20 December 2012 | Published 28 December 2012

Citation: Siti-Munirah MY (2012) Ridleyandra iminii (Gesneriaceae), a new species from Peninsular Malaysia. PhytoKeys 19: 67-70. doi: 10.3897/phytokeys.19.4064

\begin{abstract}
A new endemic species of Ridleyandra (Gesneriaceae), R. iminii Siti-Munirah from Peninsular Malaysia is described and illustrated. Among Ridleyandra species, it is the only one with a dark red flower.
\end{abstract}

\section{Keywords}

Gesneriaceae, Ridleyandra, Peninsular Malaysia, new species

\section{Introduction}

During a botanical collecting trip in 2008 to Gunung Benom, Pahang, Peninsular Malaysia, a new species of Ridleyandra was discovered: here described as Ridleyandra iminii Siti-Munirah. In Peninsular Malaysia, currently 12 species of Ridleyandra are known (Weber 1998; Kiew 2009). This is the first Ridleyandra species with deep red flowers to be described. Although in vegetative characters it resembles $R$. morganii (Franch.) A.Weber, it is completely different in the colour and patterning of the flower. The inside of the purple corolla tube of $R$. morganii has white lines on the lower surface of the throat, and the lobes are concolorous with the outside of the tube. In contrast, the corolla lobes and throat of $R$. iminii are red and contrast with the white outer surface of the tube, and the throat lacks contrasting lines. Weber has drawn attention on the coloration of Ridleyandra species. Flowers of other Ridleyandra species are yellow, white, blue or violet so the deep red throat is remarkable. 


\section{Taxonomy}

Ridleyandra iminii Siti-Munirah, sp. nov. urn:Isid:ipni.org:names:77123887-1

http://species-id.net/wiki/Ridleyandra_iminii

Figure 1

Diagnosis. Ridleyandra iminii is most similar to $R$. morganii (Franch.) A. Weber in its dentate leaves with blunt teeth more than $5 \mathrm{~mm}$ long, but it differs in its shorter peduncles (not $7-10 \mathrm{~cm}$ long), the deep red colouration of the corolla (not deep purple with white lines in the throat) and longer capsules (5-6 cm long, not $4.5-5 \mathrm{~cm}$ long).

Type. Peninsular Malaysia. Pahang, Gunung Benom, Krau Game Reserve. 8 January 2008 (fl \& fr), Siti-Munirah FRI 55387 (holotype: KEP!).

Description. Perennial herb, stem unbranched, woody, to $25 \mathrm{~cm}$ long, glabrous except for dense dark uniseriate, multicellular hairs, ca $0.5 \mathrm{~mm}$ long, on upper portion of petioles, on the lower surface of midrib and on peduncles. Leaves opposite, clustered in a rosette at the top of the stem; petioles $1-4 \mathrm{~cm}$ long; lamina lanceolateoblong, 9-18.5 × 3-5.5 cm, glossy above, slightly paler beneath, base attenuate, margin undulate, very coarsely serrate, teeth to nearly $1 \mathrm{~cm}$ long, broad and blunt, apex acute; midrib and veins impressed above, prominent beneath, lateral veins (10-)12(-16) pairs. Inflorescence single-flowered, peduncle slender, pale green, 5-8 cm long; bract pair lanceolate, $2-3 \times 1-2 \mathrm{~mm}$; pedicels $2.5-3 \mathrm{~cm}$; sepals light green, divided to base, lanceolate, $5-7 \times$ ca. $1 \mathrm{~mm}$, apex acute; corolla trumpet-shaped; tube white outside, dark red within, ca. $4 \mathrm{~cm}$ long, ca. $5 \mathrm{~mm}$ wide at base dilating to $10-15 \mathrm{~mm}$ wide at the mouth, outside finely pubescent, throat and lobes dark red, nectar guides raised and slightly darker, inner surface of throat finely velvety; lobes 5, upper two lobes reflexed, ca. $5 \times 10 \mathrm{~mm}$ and lower three lobes extending beyond the upper, ca. $5 \times 12$ $\mathrm{mm}$; stamens with filaments $2-2.5 \mathrm{~cm}$ long, anthers white, ca. $1 \times 1 \mathrm{~mm}$, connective small and horn-like, staminode vestigial; ovary and style ca. $3 \mathrm{~cm}$ long, stigma broadly triangular, white. Capsules curved downwards, glabrous, 5-6 cm long, ca. $3 \mathrm{~mm}$ thick, sepals not persisting.

Distribution: Ridleyandra iminii is known only from the type locality, Peninsular Malaysia. Pahang: Gunung Benom, Krau Game Reserve, 345'N, 102 $19^{\circ} \mathrm{E}$.

Ecology. In upper hill dipterocarp forest on wet, sandy, moist soil on a shaded, steep slope and river bank at ca. $700 \mathrm{~m}$ altitude.

Etymology. The species is named after Mr. Imin Kamin, research assistant and plant collector in the Kepong Herbarium (KEP), Forest Research Institute Malaysia, with whom I first collected the plant. Conservation status. Rare (RA). The Malaysian Rare category has the following definition: the taxon is not exposed to any known direct or plausible potential threat and does not qualify under the five IUCN criteria and it occurs in $\leq 2$ sites or has an EOO (extent of occurrence) $\leq 100 \mathrm{~km} 2$ or AOO (area 


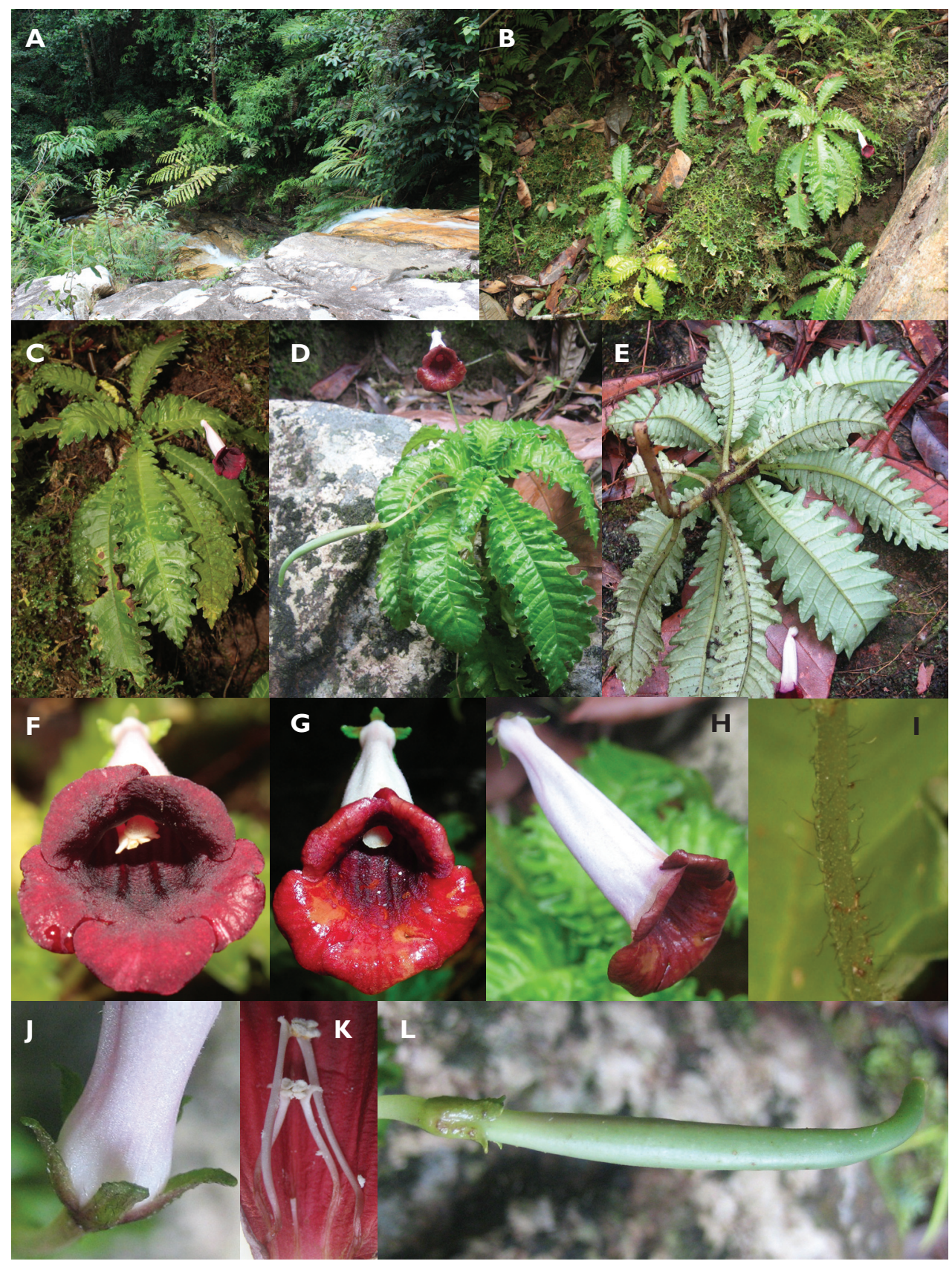

Figure I. Ridleyandra iminii. A, B habitat C-E habit $\mathbf{F}$ flower with mature stamens $\mathbf{G}$ flower with mature stigma $\mathbf{H}$ side view of flower $\mathbf{I}$ peduncle hairs $\mathbf{J}$ sepals $\mathbf{K}$ stamens and staminode $\mathbf{L}$ fruit. (Photos: A-C, F by K. Imin, D-E, G-L by M.Y. Siti-Munirah). 
of occupancy) $\leq 10 \mathrm{~km} 2$ (Chua 2012). In the case of this species, although it occurs in a Totally Protected Area (an area that is legally protected), it still vulnerable because it lies beside the main tourist trail and its population numbers about 200 individuals.

Specimens examined. Peninsular Malaysia. Pahang: Benom, Krau Game Reserve, 15 November 2009 (f), A.R. Ummul-Nazrah FRI 70717 (KEP).

\section{Acknowledgements}

This study is part of the taxonomic work for the Safeguarding the Forest Plant Diversity of Peninsular Malaysia: Flora of Peninsular Malaysia Project (01-04-01-0000 Khas2); and Documentation \& Inventory Flora of Malaysia Project based at Forest Research Institute Malaysia and fully funded by the Ministry of Science, Technology and Innovation, Malaysia (MOSTI) and 10th Malaysian Plan, respectively. I am thankful to the State Forestry Department of Pahang and the Wildlife and National Parks Department (PERHILITAN), Malaysia, for permission to make botanical collections; to the FRIM team, Imin Kamin, Mohd Nazri and Angan Atan for assistance in the field and A.R.Ummul-Nazrah for providing information on recent collections. Many thanks to R. Kiew for editing and confirming on the taxonomic status of this new species; and Dr Lillian Chua for helping me assessing the conservation status. I am grateful L.G. Saw, R.C.K. Chung, T.L. Yao, A.R Rafidah, S. Syahida-Emiza and M.T. Mohd-Faizal for their constructive advice and comments on the manuscript. Open access to this paper was supported by the Encyclopedia of Life (EOL) Open Access Support Project (EOASP).

\section{References}

Chua LSL (2012) Conservation. In: Kiew R, Chung RCK, Saw LG, Soepadmo E (Eds) Flora of Peninsular Malaysia 2, 3: 3-10

Weber A (1998) ('1997’) Revision of the genus Ridleyandra (Gesneriaceae). Beiträge zur Biologie der Pflanzen 70: 225-273.

Kiew R (2009) Three New Species of Gesneriaceae from Kelantan. Gard. Bull. Singapore 61(1): 73-79. 